\title{
PEMBERDAYAAN ORANG TUA MELALUI PENDAMPINGAN ANAK USIA DINI YANG MENJALANI LFH PADA MASA PANDEMI COVID-19 DI MOJOKERTO
}

\section{EMPOWERMENT OF PARENTS THROUGH ASSISTANCE OF EARLY CHILDREN THROUGH LFH IN THE COVID-19 PANDEMIC IN MOJOKERTO}

\author{
Lida Khalimatus Sa'diya ${ }^{1}$, Tria Wahyuningrum ${ }^{2}$ \\ STIKes Bina Sehat PPNI Mojokerto \\ Email : lidarafi2@gamial.com
}

\begin{abstract}
ABSTRAK
Berdasarkan data covid.go.id tahun 2020, anak yang positif Covid-19 usia 0-18 tahun sebanyak 82.710 orang atau 11 persen dari pasien dewasa dengan korban meninggal sebanyak 568 orang atau 2,6 persen dari pasien dewasa yang meninggal. Masa pandemi mengharuskan untuk menjaga jarak dengan orang lain. Salah satu aktivitas yang terkena dampaknya dari pandemi ini adalah sekolah, karena harus melakukan pembelajaran melalui rumah atau LFH. Tentunya pembelajaran secara daring jauh berbeda dengan pembelajaran secara tatap muka. Agar tumbuh kembang anak pada masa pandemic berlangsung optimal maka perlu menjaga kesehatan. Beberapa faktor penentu bagi perkembangan anak baik fisik maupun mental adalah peran orang tua, terutama peran seorang ibu, karena ibu adalah pendidik pertama dan utama bagi anak yang dilahirkan sampai dewasa. Anak usia dini tergolong kelompok yang rentan terpapar Covid-19. Keluarga merupakan kelompok sosial yang pertama dalam kehidupan manusia, tempat pertama dalam belajar. Peran yang selama ini dilaksanakan di satuan pendidikan beralih fungsi di satuan keluarga. Kegiatan pengabdian masyarakat bagi STIkes bina sehat PPNI Mojokerto perlu dilakukan untuk menjalankan peran orang tua melalui pendampingan anak usia dini yang menjalani LFH (Learning From Home) pada masa pandemi covid-19. Sasaran pengabdian masyarakat adalah orang tua yang memiliki anak usia dini (5-7 tahun) berjumlah 94 orang, kegiatan talkshow dilakukan live zoom dan youtube
\end{abstract}

Kata kunci : Orang Tua, Anak usia dini, Covid

\section{ABSTRACT}

Based data of covid.go.id in 2020, children who have positive Covid-19 in age 0-18 years old are 82.710 people or 11 percents of adult patients with victim died amount 568 people or 2,6 percent of adult patients who were died. In pandemic time require to keep the distance for one to each other. One of activities the impact of this pandemic are schools, because have to learning from home or LFH. Of course learn by online so different than learning by face to face. In order child development in pandemic time going on optimal so, have to keep healthy. Several determinant factors for the best child development both physically and mentally are parents, especially for mother's role. Because mother is the first or main educator for children were borned until adult age. Children at early age classified to be susceptive group from Covid-19. Family is the first social group in hudman's life, the first place for learning. Role play to do for this time in Education units change functions to family units. Public service activities for STIkes bina sehat PPNI Mojokerto has done for parents role through accompaniment to early children who LFH (Learning From Home) in covid-19 age. Goals of public services that is parents who 
have early children (5-7 years) amount 94 people,talkshow activitie have do in live zoom dan youtube

Key words : parent, early children, Covid

\section{PENDAHULUAN}

Anak merupakan aset, pewaris, dan generasi penerus bangsa. Anak diharapkan dapat tumbuh dan berkembang sebaikbaiknya sehingga nantinya menjadi orang dewasa yang sehat secara fisik, mental, sosial dan emosi, dengan demikian dapat mencapai perkembangan yang optimal akan potensi yang dimilikinya dan menjadi sumberdaya manusia yang berkualitas (Sujiono, 2013). Proses tumbuh kembang yang merupakan proses utama, hakiki dan positif pada anak, merupakan suatu yang penting pada anak tersebut. Proses tumbuh kembang berlangsung pada saat pembuahan, yaitu bersatunya sel telur ibu dengan spermatozoa ayah, sampai akhir masa remaja dengan melewati masa-masa prenatal, bayi, prasekolah, sekolah dasar dan remaja. Tahun-tahun pertama merupakan kurun waktu yang penting bagi tumbuh kembang fisik, perkembangan kecerdasan, ketrampilan motorik dan sosial, emosi, berjalan demikian cepatnya, sehingga dapat dikatakan bahwa keberhasilan tahun-tahun pertama sebagian besar menentukan masa depan anak tersebut, bila tidak terdeteksi secara nyata akan mengurangi kualitas sumberdaya manusia kelak dikemudian hari.

Faktor penentu bagi perkembangan anak baik fisik maupun mental adalah peran orang tua, terutama peranseorang ibu, karena ibu adalah pendidik pertama dan utama bagi anak-anak yang dilahirkan sampai dia dewasa. Dalam proses pembentukan pengetahuan, melalui berbagai pola asuh yang disampaikan oleh seorang ibu sebagai pendidik pertama sangatlah penting. Pendidikan dalam keluarga sangat berperan dalam mengembangkan watak, kepribadian, nilai-nilai budaya, nilai-nilai keagamaan dan moral, serta ketrampilan sederhana. Dalam konteks ini proses sosialisasi dan enkulturasi terjadi secara berkelanjutan. Hal ini bertujuan untuk membimbing anak agar menjadi manusia yang beriman, bertaqwa, berakhlak mulia, tangguh, mandiri, inovatif, kreatif, beretos kerja, setiakawan, peduli akan lingkungan, dan lain sebagainya (Masdudi, 2015).

Berdasarkan data covid.go.id tahun 2020, anak yang positif Covid-19 usia 0-18 tahun sebanyak 82.710 orang atau 11 persen dari pasien dewasa dengan korban 
meninggal sebanyak 568 orang atau 2,6 persen dari pasien dewasa yang meninggal. Dengan mewabahnya virus corona, Pemerintah Indonesia tanggap dan mulai menganjurkan warganya untuk physical distancing dan mengisolasi diri di rumah untuk mengantisipasi penyebaran virus ini makin meluas. Dalam artikel "Corona Virus Disease 2019, a Growing Threat to Children?", bahwa ancaman besar virus Corona sebenarnya terjadi pada dan melalui anak-anak. Anak usia dini tergolong kelompok yang rentan terpapar Covid-19. Aktivitas yang melibatkan banyak orang pun saat ini semakin dibatasi seperti sekolah, bekerja, beribadah, dan lain-lain. Situasi ini menimbulkan kekhawatiran, tak jarang membuat masyarakat panik. Orang tua diharapkan dapat memberi pemahaman kepada anak-anak untuk tetap di rumah. Peran orang tua melalui pendampingan anak usia dini yang menjalani LFH dalam masa pandemic covid 19 sangat diperlukan.

\section{METODE}

Sasaran dari pengabdian masyarakat ini adalah orang tua yang memiliki anak usia 5-7 tahun. Metode yang dipergunakan pada pengabdian masyarakat ini adalah pemberian edukasi kepada orang tua yang memiliki anak usia 5-7 tahun dengan tema talkshow "Belajar Di Rumah Dengan Ceria (Anak Usia Dini)" yang dilaksanakan pada hari senin 26 oktober 2020 jam 09.00-10.30, dengan live Zoom Meeting https://us02web.zoom.us/j/81768975437?pw d=ODNwY2VKQTdFc2YrY3UvOHllNFgy UT09 , Meeting ID: 8176897 5437, Passcode: binasehat dan youtube STIKes Bina Sehat PPNI Mojokerto.

Bentuk kegiatan edukasi ini meliputi :

1) Pemberian edukasi kepada orang tua yang memiliki anak usia 5-7 tahun dengan tema talkshow "Belajar Di Rumah Dengan Ceria (Anak Usia Dini)".

2) Diskusi dan tanya jawab terkait peran orang tua dalam pendampingan anak usia dini yang menjalani LFH pada masa pandemi covid-19.

Pelaksanaan kegiatan pengabdian pada masyarakat ini akan dibagi dalam beberapa tahapan, diantaranya:

\section{Tahap awal}

Sebelum pelaksanaan edukasi dimulai, peserta masuk di ruang zoom sesuai link, passcode dan username. Yang bertujuan agar terjadi komitmen antara peserta dengan pelaksana dan kegiatan dapat berjalan lancar. Peserta lebih fokus dalam mengikuti edukasi. 
2. Tahap edukasi

Tahapan pemberian edukasi dengan tema Belajar Di Rumah Dengan Ceria (Anak Usia Dini). materi difokuskan pada peran orang tua dalam pendampingan anak usia dini yang menjalani LFH pada masa pandemi covid-19.

\section{Tahap evaluasi}

Tahapan ini merupakan tahap akhir dari kegiatan pengabdiana masyarakat setelah penyampaian materi. Pada tahap ini diharapkan peserta memahami apa yang disampaikan saat edukasi oleh pemateri dan tanya jawab terkait peran orang tua dalam pendampingan anak usia dini yang menjalani LFH pada masa pandemi covid19.

\section{HASIL DAN PEMBAHASAN}

Kegiatan pengabdian kepada masyarakat dilaksanakan pada hari senin 26 oktober 2020 jam 09.00-10.30, dengan live Zoom

Meeting https://us02web.zoom.us/j/81768975437?pw d=ODNwY2VKQTdFc2YrY3UvOHllNFgy UT09, Meeting ID: 8176897 5437, Passcode: binasehat dan youtube STIKes Bina Sehat PPNI Mojokerto. Kegiatan ini dapat diterima dengan baik oleh responden dan responden sangat antusias, senang dalam mengikuti kegiatan talkshow ini.
Hasil pelaksanaan kegiatan pengabdian kepada masyarakat didapatkan hasil sebagai berikut:

\begin{tabular}{|c|c|c|c|}
\hline No & Kategori & $\mathrm{n}$ & $\%$ \\
\hline 1 & \multicolumn{3}{|c|}{ Umur } \\
\hline & $<20$ tahun & 33 & 35 \\
\hline & 20-35 tahun & 51 & 54 \\
\hline & $>35$ tahun & 11 & 11 \\
\hline \multirow[t]{4}{*}{2} & \multicolumn{3}{|c|}{ Pendidikan } \\
\hline & SMA & 76 & 80 \\
\hline & Diploma I/II & 9 & 9 \\
\hline & Strata $1 / 2 / 3$ & 10 & 11 \\
\hline \multirow[t]{5}{*}{3} & \multicolumn{3}{|c|}{ Pekerjaan } \\
\hline & Bekerja $\geq 7$ jam/hari & 13 & 14 \\
\hline & Bekerja 4-6 jam/hari & 10 & 10 \\
\hline & Bekerja $<4$ jam/hari & 0 & 0 \\
\hline & Tidak bekerja & 72 & 76 \\
\hline \multirow[t]{6}{*}{4} & \multicolumn{3}{|c|}{ Jumlah anak } \\
\hline & 1 & 6 & 6 \\
\hline & 2 & 8 & 9 \\
\hline & $\geq 3$ & 7 & 7 \\
\hline & Belum mempunyai anak & 74 & 78 \\
\hline & Total responden & 95 & 100 \\
\hline
\end{tabular}

Berdasarkan tabel 4.1 didapatkan hasil bahwa lebih dari setengah responden berusia 20-35 tahun yaitu sejumlah 51 responden $(54 \%)$, untuk pendidikan terakhir didapatkan hasil bahwa sebagian besar responden berpendiddikan SMA yaitu sejumlah 76 responden (80\%). Sedangkan untuk pekerjaan orang tua responden lebih dari setengahnya adalah tidak bekerja yaitu sebesar 72 responden (76\%). Untuk jumlah 
anak sebagian kecil yang memiliki jumlah anak 1 yaitu sebesar 6 responden (6\%).

Masa anak usia dini merupakan masa yang sangat peka terhadap sesuatu yang didapatkan dari lingkungan sekitar. Pada masa tersebut anak usia dini berkembang dengan pesat atau dikenal dengan masa golden age. Masa golden age adalah masa saat anak mudah menyerap segala informasi dan perlakuan yang ada di sekitarnya baik dari orang dewasa maupun teman sebaya. Masa-masa tersebut adalah masa kritis sehingga anak membuntuhkan rangsanganrangsangan yang tepat baik dalam bentuk latihan atau proses stimulasi.

Anak membutuhkan stimulasi dari lingkungan anak terutama lingkungan keluarga. Keluarga merupakan lingkungan pertama dan utama bagi proses perkembangan anak untuk membentuk pondasi pembentukan karakter anak. Pendidikan berawal dari keluarga yang dijadikan panutan/teladan utama bagi anak. Segala sikap, prilaku, ucapan, orang tua akan dijadikan pusat pembelajaran awal anak, dengan demikian orang tua harus cerdas menstimulasi dan berinteraksi dengan anak.

Pada saat ini pendidikan keluarga sangat penting. Hal tersebut berdasarkan perkembangan zaman yang semakin canggih. Anak-anak membutuhkan pendampingan orang tua, yaitu turut terlibat disetiap kegiatan anak di rumah serta terlibat dalam kegiatan yang dilaksanakan sekolah. Keterlibatan orang tua akan membawa dampak positif perkembangan anak untuk membentuk pondasi pembentukan karakter bagi kehidupan anak di masa depan.

\section{KESIMPULAN}

1. Kegiatan pengabdian masyarakat, dapat di ikuti oleh responden dengan baik dan aktif dalam kegiatan talkshow, karena keterbatasan waktu sehingga 6 soal saja yang bisa dijawab secara live.

2. Memberdayakan orang tua melalui pendampingan anak usia dini yang menjalani LFH dalam masa pandemi covid-19 sebagai bentuk attacment orang tua dan anak untuk menjadikan generasi penerus bangsa yang berkwalitas

\section{DAFTAR PUSTAKA}

Anggraeni, Dwiyani, Sofia Hartati, Yuliani Nurani. (2019). Implementasi Metode Bercerita dan Harga Diri dalam Meningkatkan Kemampuan Berbicara Anak Usia Dini. Jurnal Obsesi: Jurnal Pendidikan Anak Usia Dini, 3 (2), 404-415. 
Dinata, Pri Ariadi Cahya; Rahzianta; Zainuddin, Muhammad. "Self Regulated Learning sebagai Strategi Membangun Kemandirian Peserta Didik Dalam Menjawab Tantangan Abad 21", Prosiding Seminar Nasional Pendidikan Sains (SNPS) 2016.

Hatimah, Ihat. "Keterlibatan Keluarga Dalam Kegiatan Di Sekolah Dalam Perspektif Kemitraan", Pedagogia, Jurnal Ilmu Pendidikan, Vol. 14, No. 2 (2016).

Juhaina. (2015). Metode Cerita untuk Mengembangkan Aspek-aspek Perkembangan Anak. Syamil, 3(2), 195-225.
Masdudi. (2015). Karakteristik Perkembangan Pendidikan Anak Usia Dini. Jurnal Pendidikan Anak Jurusan Pendidikan Anak Usia Dini, 1 (2), 5-9.

Nursalam. 2013. Konsep Dan Penerapan Metodologi Penelitian Ilmu Keperawatan. Jakarta: Salemba Medika

Sujiono, Y N. (2013). Konsep Dasar Pendidikan Anak Usia Dini. Jakarta:PT Indeks.

Yulianingsih, Yuyun and Hayati, Tuti and Kurnia, Aam and Nursihah, Arif ,Pengenalan Covid-19 pada anak usia dini melalui metode bercerita, 2020. 